\title{
LOSS OF AMMONIA FROM NITROGEN FERTILIZERS APPLIED TO MAIZE AND SOYBEAN STRAW ${ }^{(1)}$
}

\author{
Letícia de Abreu Faria ${ }^{(2)}$, Carlos Antonio Costa do Nascimento ${ }^{(3)}$, Godofredo Cesar \\ Vitti $^{(4)}$, Pedro Henrique de Cerqueira Luz ${ }^{(5)}$ \& Elaine Maria Silva Guedes ${ }^{(6)}$
}

\begin{abstract}
SUMMARY
In Brazilian agriculture, urea is the most commonly used nitrogen $(\mathrm{N})$ source, in spite of having the disadvantage of losing considerable amounts of $\mathrm{N}$ by ammonia- $\mathrm{N}$ volatilization. The objectives of this study were to evaluate: $\mathrm{N}$ lossby ammonia volatilization from: [urea coated with copper sulfate and boric acid], [urea coated with zeolite], [urea+ammonium sulfate], [urea coated with copper sulfate and boric acid+ammonium sulfate], [common urea] and [ammonium nitrate]; and the effect of these $\mathbf{N}$ source son the maize yield in terms of amount and quality. The treatments were applied to the surface of a soil under no-tillage maize, in two growing seasons. The first season (2009/2010) was after a maize crop (maize straw left on the soil surface) and the second cycle (2012/2011) after a soybean crop. Due to the weather conditions during the experiments, the volatilization of ammonia- $\mathrm{N}$ was highest in the first four days after application of the $\mathrm{N}$ sources. Of all urea sources, under volatilization-favorable conditions, the loss of ammonia from urea coated with copper sulfate and boric acid was lowest, while under high rainfall, the losses from the different urea sources was similar, i.e., an adequate rainfall was favorablet o reduce volatilization. The ammonia volatilization losses were greatest in the first four days after application. Maize grain yield differed due to $\mathrm{N}$ application and in the treatments, but this was only observed with cultivation of maize crop residues in 2009/2010. The combination of ammonium+urea coated with copper sulfate and boric acid optimized grain yield compared to the other urea treatments. The crude protein concentration in maize was not influenced by the technologies of urea coating.
\end{abstract}

Index terms: boric acid, copper sulfate, coated urea, volatilization, zeolite.

(1) Received for publication on August 2, 2012 and approved on May 21, 2013.

(2) $\mathrm{PhD}$ candidate in Soil Science and Plant Nutrition Graduate Program - ESALQ/USP. FAPESP grantee. Av. Pádua Dias, 11. P.O. Box 9. CEP 13418-900 Piracicaba (SP), Brazil. E-mail: evazoot@yahoo.com.br

(3) PhD candidate in Soil Science and Plant Nutrition Graduate Program - ESALQ-USP. Capes grantee. E-mail: cacnagro@yahoo.com.br

(4) Professor at Soil Science Department, ESALQ-USP. E-mail: gcvitti@usp.br

(5) Professor at Animal Science Department -FZEA/USP. Av. Duque de Caxias, 225. CEP 13635-900 Pirassununga (SP), Brazil. E-mail: phcerluz@usp.br

(6) Professor I at Universidade Federal Rural da Amazônia. E-mail: elaine.guedes@ufra.edu.br 


\title{
RESUMO: PERDAS DE N-NH $\mathrm{H}_{3}$ DE FERTILIZANTES NITROGENADOS APLICADOS EM PALHADAS DE MILHO E DE SOJA
}

\begin{abstract}
A ureia é a fonte de $N$ mais utilizada; entretanto, esse fertilizante tem sérios problemas por apresentar elevadas perdas de $N$-amônia por volatilização. Os objetivos deste estudo foram avaliar as perdas por volatilização de $N$-amônia, provenientes de ureia revestida com sulfato de cobre e ácido bórico, ureia revestida com zeólita, misturas de ureia+sulfato de amônio, ureia revestida+sulfato de amônio e ureia e nitrato de amônio; e determinar seus efeitos na produtividade e qualidade do milho, com aplicação em cobertura na cultura de milho manejada em sistema de plantio direto em duas safras agrícolas, em que a primeira encontrava-se com cultivo sequencial de milho em 2009/2010; e, a segunda, com cultivo do milho após soja, em 2010/2011. Diante das condições climáticas ocorridas, o pico de perdas de $N$-amônia por volatilização situou-se nos primeiros dias, após a aplicação das fontes avaliadas. Dentre as fontes com ureia, a ureia revestida com sulfato de cobre e ácido bórico apresentou redução na perda de amônia em condições favoráveis à volatilização, enquanto, sobre condições de elevada precipitação, as fontes com ureia foram similares, ou seja, as condições de precipitação adequadas foram favoráveis à redução da volatilização. As maiores perdas de amônia por volatilização ocorreram durante os primeiros quatro dias, após aplicação. Houve diferenças na produção de grãos como resultado da aplicação de nitrogênio, bem como para os tratamentos, porém isso foi observado somente com cultivo em resíduo cultural de milho na safra 2009/2010. A mistura de sulfato de amônio + ureia revestida com sulfato de cobre e ácido bórico resultou em maior produção de grãos, comparada aos demais tratamentos com ureia. As tecnologias usadas juntamente com a ureia não modificaram os teores de proteína bruta.
\end{abstract}

Termos de indexação: ácido bórico, sulfato de cobre, ureia revestida, volatilização, zeólita.

\section{INTRODUCTION}

Urea is one of the most commonly used nitrogen (N) sources in the Brazilian agriculture. Unfortunately, due to its characteristics and reactivity in soil, it is highly prone to lose ammonia by volatilization (Keller \& Mengel, 1986; Lara Cabezas \& Trivelin, 1990). Losses of 50 to $94 \%$ were reported by Oliveira et al. (1997) when urea was applied to soil surface covered by straw. The efficiency of urea depends on its mixing into the soil (Lara Cabezas et al., 2008), but since this practice is expensive and involves a series of other issues related to the application rate, farmers are somewhat resistant to adopt this practice.

The no-tillage and minimum tillage systems have been successfully used in Brazilian agriculture. For example, the area under no tillage in Brazil was 0.1 million hectares in 1972/1973 and increased to 25.5 million hectares in 2005/2006, becoming the second largest no-tillage area in the world (FEBRAPDP, 2009). The use of materials to coat urea grains or for a combined application together with urea could be an option to increase the efficient use of this $\mathrm{N}$ source. Zeolites have been evaluated as reducers of urea volatilization (Bernardi et al., 2007a,b; Bartz \& Jones, 1983; Ferguson \& Pepper, 1987) due to their high cation exchange capacity, water retention capacity and capability to adsorb $\mathrm{N}-\mathrm{NH}_{4}{ }^{+}$, and can be added to fertilizers to diminish $\mathrm{N}$ loss by $\mathrm{NH}_{3}$ volatilization (Fansuri et al., 2008).
It was also shown that boric acid and copper sulfate as coating of urea grains have positive effects in reducing $\mathrm{N}$ volatilization losses (Fansuri et al., 2008). The acidifying effect, the similar structural characteristics of boric acid with urea and the defensive effect of $\mathrm{B}$ and $\mathrm{Cu}$ from the soil microorganisms may deviate part of the urease activity towards boric acid, and consequently decrease $\mathrm{N}$ volatilization losses.

The use of ammonium sulfate mixed with urea was evaluated by Lara Cabezas et al. (1997), Vitti et al. (2002) and Lara Cabezas \& Souza (2008), who also observed a positive effect in reducing $\mathrm{N}$ volatilization. According to Lara Cabezas et al. (1997), ammonium sulfate in acid soils would be an additional source of protons.

The development of technologies to increase the efficacy of urea applied to the soil surface by decreasing the volatilization of ammonia- $\mathrm{N}$ in conservation management systems is still a challenge. The use of zeolites, coating with boric acid and copper sulfate and blends with ammonium sulfate would result in decreased ammonia- $\mathrm{N}$ volatilization and as a consequence, higher maize yields. The objectives of this study were to evaluate: the loss of $\mathrm{N}$ by volatilization of ammonia- from [urea coated with copper sulfate and boric acid], [urea coated with zeolite], [urea+ammonium sulfate], [urea coated with copper sulfate and boric acid+ammonium sulfate], [common urea] and [ammonium nitrate]; and the effect of these $\mathrm{N}$ sources on maize yields in terms of amount and quality. 


\section{MATERIAL AND METHODS}

The experiment was carried out in Pirassununga, São Paulo State, Brazil. The area was managed in a no-tillage system. Maize was studied in two maize growing seasons, fertilized with $450 \mathrm{~kg} \mathrm{ha}^{-1}$ of 8-16$16 \mathrm{NPK}$ fertilizer +0.5 of $\mathrm{Zn}$ and $0.2 \mathrm{~B}$ at sowing. The first season (2009/2010) was after a maize crop, whose straw had been left on the soil surface, and the second maize crop (2010/2011) was grown after soybean. The experimental areas were close to each other and the soil was a Latossolo Vermelho by the Brazilian Soil Classification System (Embrapa, 2006). The components of the soil texture consisted of $226 \mathrm{~g} \mathrm{~kg}^{-1}$ sand, $262 \mathrm{~g} \mathrm{~kg}^{-1}$ silt, and $512 \mathrm{~g} \mathrm{~kg}^{-1}$ clay. The soil chemical characteristics before sowing are shown in table 1 .

The weather conditions during the experiment were monitored by a meteorological station on the campus of Faculdade de Zootecnia e Engenharia de Alimentos and a pluviometer installed in the experimental area (Figure 1).
The experiment was arranged in a complete randomized block design with seven treatments and four replications. Each experimental unit consisted of six $10-\mathrm{m}$-long maize rows ( $0.8 \mathrm{~m}$ between rows), with a total area of $48 \mathrm{~m}^{2}$ each. Topdressing was applied in a band in a single dose of $100 \mathrm{~kg} \mathrm{ha}^{-1} \mathrm{~N}$ on the soil surface, when plants had four to six leaves. The treatments were represented by the sources: Urea coated with boric acid $(0.4 \% \mathrm{~B})$ and copper sulfate $(0.14 \% \mathrm{Cu})$, (UC-B/Cu); Ammonium Nitrate, (NA); Urea (U); Ammonium Sulfate (33.3\%)+Urea (66.7\%), (ASU); Ammonium Sulfate (33.3\%)+Urea coated with boric acid and copper sulfate (66.7\%), (ASUC-B/Cu); Urea coated with Zeolite (UC-Z), $(15 \% \mathrm{~m} / \mathrm{m})$; and a control.

Gypsum was also applied (an amount equivalent to $40 \mathrm{~kg} \mathrm{ha}^{-1} \mathrm{~S}$ ) in the treatments without ammonium sulfate, to ensure similar sulfur availability in all units. The control treatment was used as a correction factor in the calculations of ammonia losses from fertilizer by the method of ammonia collectors. The collectors,

Table 1. Soil chemical analyses of samples from the experimental sites

\begin{tabular}{|c|c|c|c|c|c|c|c|c|c|c|c|c|c|c|c|c|c|}
\hline Cycle & Layer & $\mathrm{pH}\left(\mathrm{CaCl}_{2}\right)$ & $\mathbf{O M}$ & $\mathbf{P}$ & $\mathbf{S}$ & $\mathbf{C a}$ & $\mathbf{M g}$ & $\mathbf{K}$ & $\mathbf{H}+\mathbf{A l}$ & CTC & SB & $\mathbf{V}$ & B & $\mathbf{C u}$ & $\mathbf{F e}$ & Mn & $\mathbf{Z n}$ \\
\hline & $\mathrm{cm}$ & & $\mathrm{g} \mathrm{dm} \mathrm{m}^{-3}$ & \multicolumn{2}{|c|}{$\mathrm{mg} \mathrm{dm}{ }^{-3}$} & \multicolumn{6}{|c|}{$\mathrm{mmol}_{\mathrm{c}} \mathrm{dm}^{-3}$} & $\%$ & \multicolumn{5}{|c|}{$-\mathrm{mg} \mathrm{dm} \mathrm{m}^{-3}$} \\
\hline \multirow[t]{2}{*}{$2009 / 10$} & $0-20$ & 6.2 & 39 & 31 & 13 & 44 & 26 & 5 & 19 & 94 & 75 & 80 & 0.61 & 1.8 & 22 & 20.9 & 1.8 \\
\hline & $20-40$ & 6.0 & 26 & 29 & 15 & 33 & 20 & 5 & 23 & 81 & 58 & 72 & 0.17 & 3.0 & 14 & 30.9 & 2.7 \\
\hline \multirow[t]{2}{*}{$2010 / 11$} & $0-20$ & 5.7 & 25 & 43 & 5 & 33 & 13 & 3 & 25 & 74 & 49 & 66 & 0.20 & 1.5 & 16 & 19.9 & 1.9 \\
\hline & $20-40$ & 5.4 & 23 & 17 & 11 & 23 & 12 & 3 & 27 & 65 & 38 & 58 & 0.16 & 1.2 & 14 & 14.9 & 0.8 \\
\hline
\end{tabular}

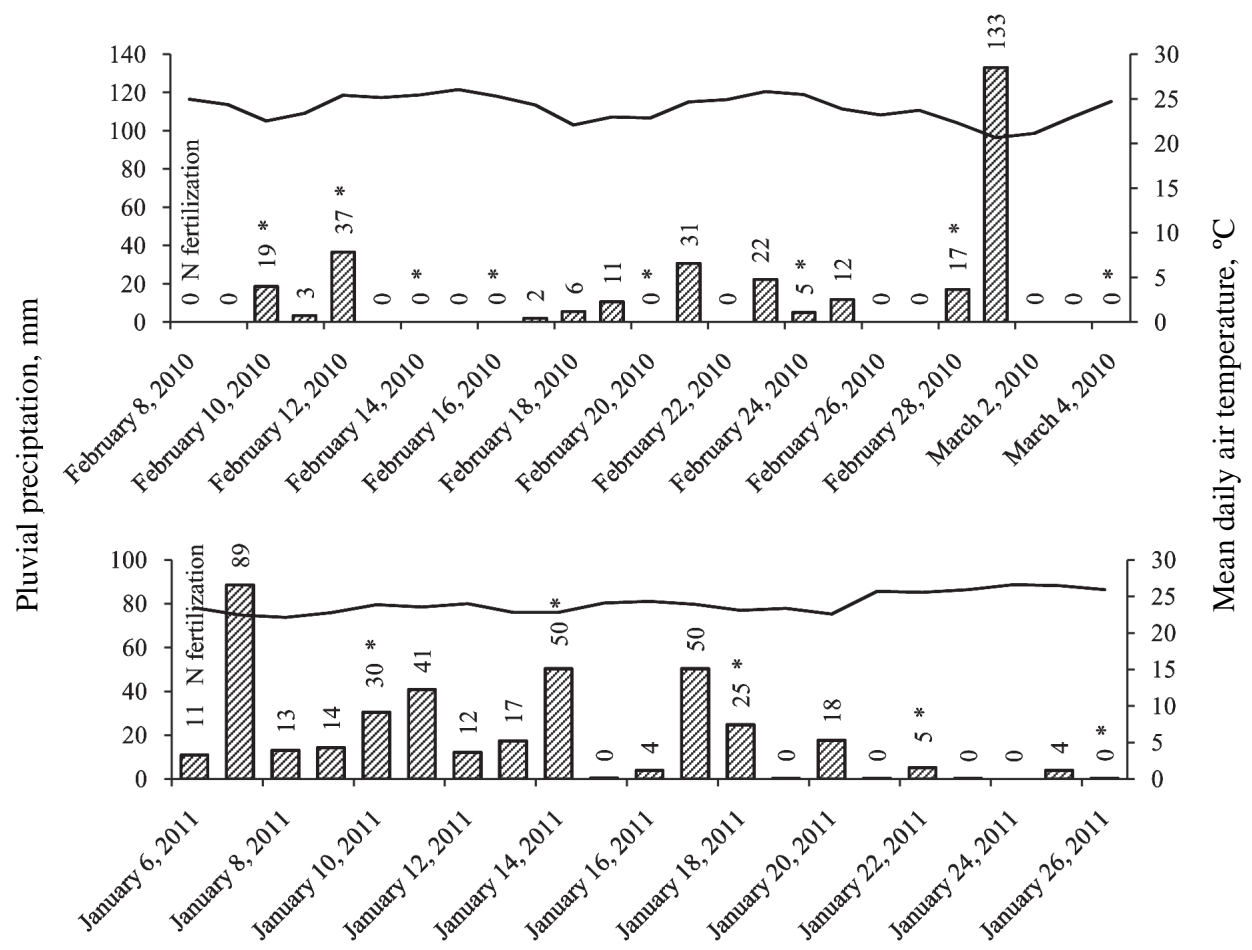

Figure 1. Total local rainfall and mean daily temperature at the experimental sites in the $2009 / 2010$ (a) and 2010/2011 (b) growing seasons. *: dates of volatilization measurements. 
each with five bases, were installed at the same time as fertilization was applied, to measure $\mathrm{N}$ loss through ammonia- $\mathrm{N}$ volatilization. The direct method was used to measure $\mathrm{N}$ volatilization with an adaptation of the static semi-open $\mathrm{NH}_{3}$ collectors of Nömmik (1973) in the dynamic mode, i.e., shifting the collector to the following basis at each evaluation. The correction factors used were proposed by Lara Cabezas et al. (1999) to correct the low efficiency of the collectors to quantify the volatilized ammonia. The treatments were evaluated $4,8,12,16$, and 20 day safter application, using new foams saturated with phosphoric acid for each measurement. The collectors and the five bases were installed in the medium third portion of the third row of each experimental unit and in the line of fertilizer (treatments) application.

The upper foams were discarded and the lower foams were stored under refrigeration $\left(5^{\circ} \mathrm{C}\right)$ until analysis. Each foam was placed in a porcelain funnel coupled to a vacuum pump and washed with $400 \mathrm{~mL}$ of deionized water. A $50 \mathrm{~mL}$ aliquot of this extract was used to distillate ammonia- $\mathrm{N}$ and determine $\mathrm{N}$ by the Kjedahl method.

Maize was harvested by hand and the yield determined as grain mass (adjusted to $13 \%$ moisture). Grain quality was evaluated based on the measurement of the mass of 1000 grains and the crude protein concentration (GP) using the micro-Kjeldahl method (AOAC, 1990).

After data correction according to Lara Cabezas et al. (1999), results were analyzed by the statistical software package SAS (2004). To evaluate the urea treatments, data were compared using orthogonal contrasts and the significance level among all treatments was evaluated by the Tukey test $(p<0.05)$.

\section{RESULTS AND DISCUSSION}

The loss of ammonia-N from urea was less than $20 \%$ of the total amount applied in both years (Table 2), which can be considered a small loss, compared to literature reports, e.g., of Oliveira et al. (1997), who found a loss of 50 to $94 \%$ when urea was applied to a straw-covered soil surface.

The weather conditions immediately after fertilizer application in the 2009/2010 season (Figure 1) were favorable for $\mathrm{N}$ volatilization. The highest loss of ammonia-N through volatilization was observed in the first four days after application for all $\mathrm{N}$ sources (Table 3) in both growing seasons. The peak of $\mathrm{NH}_{3}$ volatilization usually occurs during these first days, according to Pereira et al. (2009), Vitti et al. (2002) and Cantarella et al. (2003).

A smaller loss of ammonia-N was observed in the treatment of urea coated with boric acid and copper sulfate in the experiment in the $2009 / 2010$, but not in the 2010/2011 season (Table 2). The reason was probably that in the 2010/2011 season rainfall was high in the few days after fertilization (Figure 1). Rain reduces volatilization by dissolving urea into the soil (Cantarella et al., 1999).

Volatilization of ammonia-N from the combinations of urea or coated urea and ammonium sulfate did not differ from urea in both seasons (Table 2). These results disagree with those reported by Vitti et al. (2002) and Lara Cabezas et al. (2008), who observed smaller losses from the combinations than from urea alone.

The use of urea plus $15 \%(\mathrm{~m} / \mathrm{m})$ of zeolites did not reduce volatilization compared to urea alone, in disagreement with results reported by Bernardi et al. (2007a), who observed a volatilization reduction of more than $20 \%$.

The higher grain yield in the $\mathrm{N}$ fertilization than the control treatment (without $\mathrm{N}$ ) was only observed in the 2009/2010 season (Table 2). The influence of soil fertility on crop response was described by Mulvaney et al. (2001) and the results of that study reinforced the concept to take the previous crop into consideration when planning $\mathrm{N}$ fertilization, as also discussed by Amado et al. (2002). Agricultural soil managements that use organic matter input and recycling in soil, e.g., the no-tillage system, intensify the microbial activity and its role in mineralizing $\mathrm{N}$ from organic sources for plants (Cantarella, 2007). Therefore, the lack of response to $\mathrm{N}$ fertilizers in the 2010/2011 growing season would be a consequence of both climatic conditions and the composition of the soil residuum (richer in $\mathrm{N}$ than residues of the previous season). Due to this mechanism, Amado et al. (2002) suggests the use of lower $\mathrm{N}$ doses for crops sown after leguminous crops.

No correlation was observed between ammonia volatilization and crop yield, possibly because of the small and similar ammonia losses in the treatments. In general, the recovery of fertilized $\mathrm{N}$ by plants is low. Fernandes et al. (1999) observed recovery by plants of 10 to $52 \%$, depending on the soil management. In other words, soil is the main $\mathrm{N}$ reservoir of maize crops and fertilizers would therefore influence the $\mathrm{N}$ stock of the crop system over time.

The maize grain yield was higher when fertilized with the mixture of urea coated with boric acid and copper sulfate with ammonium sulfate than in the other treatments using urea in the 2009/2010 growing season; however, in the same season, the yield of maize treated with the same mixture without urea coating was lower than in the other treatments using urea (Table 2). The yield in the treatment with urea mixed with ammonium sulfate was different from that reported by Lara Cabezas et al. (2008), which was significantly greater than the control, but similar to the mixed sources urea+ammonium 
Table 2. Orthogonal contrasts and significance of the total volatilized ammonia- $\mathrm{N}$ in the 2009/2010 and 2010/ 2011 growing seasons

\begin{tabular}{|c|c|c|c|c|c|c|}
\hline \multirow[t]{3}{*}{ Treatment } & \multicolumn{2}{|c|}{ Ammonia volatilized } & \multicolumn{2}{|c|}{ Grain yield } & \multicolumn{2}{|c|}{ Crude protein } \\
\hline & \multicolumn{4}{|c|}{ - $\mathrm{kg} \mathrm{ha}^{-1}$} & \multicolumn{2}{|c|}{$\%$} \\
\hline & $2009 / 10$ & $2010 / 11$ & $2009 / 10$ & $2010 / 11$ & $2009 / 10$ & $2010 / 11$ \\
\hline Control & - & - & 5188 & 9342 & 7.4 & 9.3 \\
\hline $\mathrm{UC}-\mathrm{B} / \mathrm{Cu}$ & 11 & 17 & 6273 & 9870 & 8.1 & 9.3 \\
\hline $\mathrm{AN}$ & 0.1 & 0 & 5288 & 9338 & 8.6 & 8.9 \\
\hline ASU & 18 & 15 & 5658 & 9853 & 8.6 & 9.3 \\
\hline ASUC-B/Cu & 19 & 12 & 7448 & 9679 & 8.5 & 9.3 \\
\hline $\mathrm{U}$ & 18 & 14 & 6278 & 9766 & 8.7 & 8.9 \\
\hline UC-Z & 19 & 14 & 5795 & 9331 & 8.0 & 9.5 \\
\hline $\mathrm{CV}(\%)$ & 27 & 19 & 9 & 8 & 11 & 8 \\
\hline Contrasts & \multicolumn{6}{|c|}{ F Test } \\
\hline Control vs UC-B/Cu + U + ASU + ASUC-B/Cu + & $+\mathrm{AN}-$ & - & $-953 * *$ & $-298^{\mathrm{ns}}$ & $-1.0 *$ & $0^{\mathrm{ns}}$ \\
\hline $\mathrm{UC}-\mathrm{B} / \mathrm{Cu}$ vs $\mathrm{U}+\mathrm{ASU}+\mathrm{ASUC}-\mathrm{B} / \mathrm{Cu}+\mathrm{UC}-\mathrm{Z}$ & $-7.9 * *$ & $1.8^{\mathrm{ns}}$ & $-47^{\mathrm{ns}}$ & $213^{\mathrm{ns}}$ & $-0.3^{\mathrm{ns}}$ & $0^{\mathrm{ns}}$ \\
\hline ASU vs UC-B/Cu + U + ASUC-B/Cu + UC-Z & $1.7^{\mathrm{ns}}$ & $1.2^{\mathrm{ns}}$ & $-816^{*}$ & $192^{\mathrm{ns}}$ & $0.3^{\mathrm{ns}}$ & $0^{\mathrm{ns}}$ \\
\hline ASUC-B/Cu vs UC-B/Cu $+\mathrm{U}+\mathrm{ASU}+\mathrm{UC}-\mathrm{Z}$ & $2.6^{\mathrm{ns}}$ & $-2.4^{\mathrm{ns}}$ & $1547 * *$ & $-26^{\mathrm{ns}}$ & $0.1^{\mathrm{ns}}$ & $0^{\mathrm{ns}}$ \\
\hline $\mathrm{U}$ vs $\mathrm{UC}-\mathrm{B} / \mathrm{Cu}+\mathrm{ASU}+\mathrm{ASUC}-\mathrm{B} / \mathrm{Cu}+\mathrm{UC}-\mathrm{Z}$ & $1.2^{\mathrm{ns}}$ & $0.1^{\mathrm{ns}}$ & $-40^{\mathrm{ns}}$ & $83^{\text {ns }}$ & $0.4^{\mathrm{ns}}$ & $0.5^{\mathrm{ns}}$ \\
\hline $\mathrm{UC}-\mathrm{Z}$ vs $\mathrm{UC}-\mathrm{B} / \mathrm{Cu}+\mathrm{U}+\mathrm{ASU}+\mathrm{ASUC}-\mathrm{B} / \mathrm{Cu}$ & $2.4^{\mathrm{ns}}$ & $-0.7^{\mathrm{ns}}$ & $-644^{*}$ & $-461^{\mathrm{ns}}$ & $0.5^{\mathrm{ns}}$ & $0.3^{\mathrm{ns}}$ \\
\hline
\end{tabular}

UC-B/Cu (urea coated with boric acid and copper sulfate); AN (ammonium nitrate); U (urea); ASU(ammonium sulfate+urea); ASUC-B/Cu (ammonium sulfate+ureacoated with $\mathrm{H}_{3} \mathrm{BO}_{4}$ and $\mathrm{CuSO}_{4}$ ); UC-Z (urea coated with zeolite); ns: non-significant; * and ${ }^{* *}$ : significant at 5 and $1 \%$ by the $\mathrm{F}$ test, respectively.

Table 3. Volatilization of ammonia-N measured in different periods after fertilizer application during the 2009/2010 and 2010/2011 growing seasons

\begin{tabular}{|c|c|c|c|c|c|}
\hline \multirow{3}{*}{ Treatment } & \multicolumn{5}{|c|}{ Day after fertilizer application } \\
\hline & 4 & 8 & 12 & 16 & 20 \\
\hline & \multicolumn{5}{|c|}{$\mathrm{NH}_{3}$ volatilization $\left(\mathrm{kg} \mathrm{ha}^{-1}\right)$} \\
\hline & \multicolumn{5}{|c|}{$2009 / 2010$} \\
\hline $\mathrm{UC}-\mathrm{B} / \mathrm{Cu}$ & $10.5 \mathrm{ab}$ & $12.8 \mathrm{ab}$ & $13.3 \mathrm{~b}$ & $13.6 \mathrm{~b}$ & $13.7 \mathrm{~b}$ \\
\hline $\mathrm{AN}$ & $0.4 \mathrm{a}$ & $0.6 \mathrm{a}$ & $0.6 \mathrm{a}$ & $0.6 \mathrm{a}$ & $0.8 \mathrm{a}$ \\
\hline ASU & $16.8 \mathrm{~b}$ & $20.1 \mathrm{~b}$ & $20.8 \mathrm{~b}$ & $21.1 \mathrm{~b}$ & $21.2 \mathrm{~b}$ \\
\hline ASUC-B/Cu & $12.9 \mathrm{~b}$ & $14.9 \mathrm{~b}$ & $15.7 \mathrm{~b}$ & $15.9 \mathrm{~b}$ & $16.1 \mathrm{~b}$ \\
\hline $\mathrm{U}$ & $14.8 \mathrm{~b}$ & $16.7 \mathrm{~b}$ & $17.6 \mathrm{~b}$ & $18.0 \mathrm{~b}$ & $18.0 \mathrm{~b}$ \\
\hline UC-Z & $15.7 \mathrm{~b}$ & $17.6 \mathrm{~b}$ & $18.3 \mathrm{~b}$ & $18.5 \mathrm{~b}$ & $18.7 \mathrm{~b}$ \\
\hline \multirow[t]{2}{*}{$\mathrm{CV}(\%)$} & 41 & 40 & 38 & 37 & 37 \\
\hline & \multicolumn{5}{|c|}{$2010 / 2011$} \\
\hline $\mathrm{UC}-\mathrm{B} / \mathrm{Cu}$ & $15.8 \mathrm{~b}$ & $16.1 \mathrm{~b}$ & $16.1 \mathrm{~b}$ & $16.3 \mathrm{~b}$ & $16.4 \mathrm{~b}$ \\
\hline $\mathrm{AN}$ & $0.4 \mathrm{a}$ & $0.6 \mathrm{a}$ & $0.7 \mathrm{a}$ & $0.8 \mathrm{a}$ & $0.8 \mathrm{a}$ \\
\hline $\mathrm{ASU}$ & $14.1 \mathrm{~b}$ & $14.3 \mathrm{~b}$ & $14.4 \mathrm{~b}$ & $14.5 \mathrm{~b}$ & $14.5 \mathrm{~b}$ \\
\hline ASUC-B/Cu & $11.4 \mathrm{~b}$ & $12.0 \mathrm{~b}$ & $12.1 \mathrm{~b}$ & $12.2 \mathrm{~b}$ & $12.2 \mathrm{~b}$ \\
\hline $\mathrm{U}$ & $13.8 \mathrm{~b}$ & $14.0 \mathrm{~b}$ & $14.1 \mathrm{~b}$ & $14.1 \mathrm{~b}$ & $14.2 \mathrm{~b}$ \\
\hline UC-Z & $13.1 \mathrm{~b}$ & $13.4 \mathrm{~b}$ & $13.4 \mathrm{~b}$ & $13.5 \mathrm{~b}$ & $13.5 \mathrm{~b}$ \\
\hline $\mathrm{CV}(\%)$ & 18 & 19 & 19 & 18 & 18 \\
\hline
\end{tabular}

UC-B/Cu (urea coated with boric acid and copper sulfate); AN (ammonium nitrate); U (urea); ASU (ammonium sulfate+urea); ASUC-B/Cu (ammonium sulfate+urea coated with $\mathrm{H}_{3} \mathrm{BO}_{4}$ and $\mathrm{CuSO}_{4}$ ); UC-Z (urea coated with zeolite). Averages followed by same letter in a column do not differ statistically by the Tukey test $(p=0.05)$. sulfate and urea+gypsum.Urea coated with zeolite influenced the grain yield negatively in the 2009/ 2010 growing season, compared to the urea treatments (Table 2).

Association between the available forms of $\mathrm{B}$ and $\mathrm{Cu}$ and sulfur from the combination of ammonium sulfate+coated urea with boric acid and copper sulfate probably induced a synergistic effect that increased grain yield, as suggested by Galrão \& Andrade (1992). The grain quality based on the assessment of crude protein was unaffected by the fertilizer treatments, but $\mathrm{N}$ application had a positive effect in the 2009/10 growing season (Table 2).

\section{CONCLUSIONS}

1. The greatest loss of ammonia- $\mathrm{N}$ by volatilization occurred in the first four days after application.

2. Using urea coated with boric acid and copper sulfate under volatilization-favorable conditions resulted in a reduction of the volatilization loss of ammonia- $\mathrm{N}$ when compared to the other urea application treatments.

3. The grain yield differed in response to nitrogen applications and urea treatments, however only when applied on maize residues. The combination of ammonium sulfate+coated urea with boric acid and 
copper sulfate resulted in a higher grain yield than of the urea treatments;

4. The crude protein content in maize grain was not influenced by the technologies of urea coating.

\section{ACKNOWLEDGEMENT}

The authors thank the Fundação de Amparo à Pesquisa de São Paulo (FAPESP) for financial support to develop the project.

\section{LITERATURE CITED}

AMADO, T.J.C.; MIELNICZUK, J. \& AITA, C. Recomendação de adubação nitrogenada para o milho no RS e SC adaptada ao uso de culturas de cobertura do solo sob sistema de plantio direto. R. Bras. Ci. Solo, 26:241-248, 2002.

ASSOCIATION OF OFFICIAL ANALYTICAL CHEMISTSAOAC.Official methods of analysis. 15.ed. Washington, D.C., 1990. 1141p.

BARTZ, J.K. \& JONES, R.L. Availability of nitrogen to sudangrass from ammonium- saturated clinoptilolite. Soil Sci. Soc. Am. J., 47:259-262, 1983.

BERNARDI, A.C.C.; OLIVEIRA, P.P.A. \& ALVES, A.C. Adição de zeólita para redução da volatilização de amônia em solo fertilizado com ureia. São Carlos, Embrapa Pecuária Sudeste, 2007a. (Circular Técnica, 55)

BERNARDI, A.C.C.; PAIVA, P.R.P. \& MONTE, M.B.M. Produção de matéria seca e teores de nitrogênio em milho para silagem adubado com ureia misturada a zeólita. São Carlos, Embrapa Pecuária Sudeste, 2007b. (Comunicado Técnico, 77)

CANTARELLA, H.; MATTOS JR.,D.; QUAGGIO, J.A. \& RIGOLIN, A.T. Fruit yield of Valencia sweet orange fertilized with different $\mathrm{N}$ sources and the of applied. Nutr. Cycling Agroecosyst., 67:215-223, 2003.

CANTARELLA, H. Nitrogênio. In: NOVAIS, R.F.; ALVAREZ V., V.H.; BARROS, N.F.; FONTES, R.F.F.; CANTARUTTI, R.B. \& NEVES, J.C.L., eds. Fertilidade do solo. Viçosa, MG, Sociedade Brasileira de Ciência do Solo, 2007. p.92132.

CANTARELlA, H.; ROSSETO, R.; BARBOSA, W.; PENNA, M.J. \& RESENDE, L.C.L. Perdas de nitrogênio por volatilização da amônia e resposta da cana-de-açúcar à adubação nitrogenada em sistema de colheita de cana sem queima prévia. In: CONGRESSO NACIONAL DA STAB, 7., Londrina, 1999. Anais... Londrina, STAB, 1999. p.82-87.

EMPRESA BRASILEIRA DE PESQUISA AGROPECUÁRIA EMBRAPA. Centro Nacional de Pesquisa de Solos. Sistema brasileiro de classificação de solos. 2.ed. Rio de Janeiro, 2006. 306p.
FEDERAÇÃO BRASILEIRA DE PLANTIO NA PALHA FEBRAPDP. Evolução da área de plantio direto no Brasil. Available at: <http://www.agri.com.br/febrapdp>. Accessed: Aug.11, 2009.

FANSURI, H.; PRITCHARD, D. \& ZHANG, D. Manufacture of Low-grade zeolites from fly ash for fertilizer applications. Curtin University of Technology, Australia, Cooperative Research Center for Coal in Sustainable Development, 2008. (Research Report Australia)

FERGUSON, G. \& PEPPER, I. Ammonium retention in soils amended with clinoptilolite. Soil Sci. Soc. Am. J., 51:231234, 1987.

FERNANDES, L.A.;VASCONCELLOS, C.A.; FURTINI NETO, A.E.; ROSCOE, R. \& GUEDES, G.A.A. Preparo do solo e adubação nitrogenada na produção de grãos e matéria seca e acúmulo de nutrientes pelo milho. Pesq. Agropec. Bras., 34:1691-1698, 1999.

GALRÃO, E.Z. \& ANDRADE, R.P. Aplicação de micronutriente, cobalto e enxofre no rendimento de sementes de estilosantes em solo de cerrado. Pesq. Agropec.Bras., 27:237-240, 1992.

KELLER, G.D. \& MENGEL, D.E. Ammonia volatilization from nitrogen fertilizers surface applied to no-till corn. Soil Sci. Soc. Am. J., 50:1060-1063, 1986.

LARA CABEZAS, W.A.R.; RODRIGUES, C.R.; OLIVEIRA, S.M. \& BORGES, E.N. Utilização de ureia em misturas com sulfato de amônio ou com gesso na cultura de milho. $R$. Bras. Ci. Solo, 32:2343-2353, 2008.

LARA CABEZAS, W.A.R. \& SOUZA, M.A. Volatilização de amônia, lixiviação de nitrogênio e produtividade de milho em resposta à aplicação de misturas de ureia com sulfato de amônio ou com gesso agrícola. R. Bras. Ci. Solo, 32:2331-2342, 2008.

LARA CABEZAS, W.A.R. \& TRIVELIN, P.C.O. Eficiência de um coletor semi-aberto estático na quantificação de amônia-N volatilizado da ureia aplicada ao solo. R. Bras. Ci. Solo, 14:345-352, 1990.

LARA CABEZAS, W.A.R.; TRIVELIN, P.C.O.; BENDASSOLLI, J.A. \& GASCHO, G.J. Calibration of a semi-open static collector for determination of ammonia volatilization from nitrogen fertilizers. Commun. Soil Sci. Plant Anal., 30:389406, 1999.

LARA CABEZAS, W.A.R.; KORNDORFER, G.H. \& MOTTA, S.A. Volatilização de amônia-N na cultura de milho: I Efeito da irrigação e substituição parcial da ureia por sulfato de amônio. R. Bras. Ci. Solo, 21:481-487, 1997.

MULVANEY, R.L.; KHAN, S.A.; HOEFT, R.G. \& BROWN, H.M.A soil organic nitrogen fraction that reduces the need for nitrogen fertilization. Soil Sci. Soc. Am. J., 65:1164-1172, 2001.

NÖMMIK, H. The effect of pellet size on the ammonia loss from urea applied to forest soils. Plant Soil, 39:309-318, 1973.

OLIVEIRA, M.W.; GAVA, G.J.C.; VITTI, G.C.; BENDASSOLI, J.A. \& TRIVELIN, P.C.O. Volatilização de amônia proveniente da ureia $(15 \mathrm{~N})$ aplicada em um solo cultivado com cana-de-açúcar. In: ENCONTRO CIENTÍFICO DOS PÓS-GRADUANDOS DO CENA/USP, 3., Piracicaba, 1997. Anais... Piracicaba, CENA-USP, 1997. p.28. 
PEREIRA, H.S.P.; LEÃO, A.F.; VERGINASSI, A. \& CARNEIRO, M.A.C. Ammonia volatilization of urea in the out-of-season corn. R. Bras. Ci. Solo, 33:1685-1694, 2009.

SAS Institute Inc. SAS OnlineDoc® 9.1.3. Cary, 2004.
VITTI, G.C.; TAVARES Jr., J.E.; LUZ, P.H.C.; FAVARIN, J.L. \& COSTA, M.C.G. Influência da mistura de sulfato de amônio com ureia sobre a volatilização de nitrogênio amoniacal. R. Bras. Ci. Solo, 26:663-671, 2002. 